\title{
Suomen kielen syntaksin kehitys vuoden ja kahdeksan kuukauden ja kolmen ikävuoden välillä
}

\author{
Taija SaikKonen
}

\section{Väitöksenalkajaisesitelmä Helsingin yliopistossa 22. toukokuuta 2018}

Suurin osa meistä tietää, kuinka vaikeaa vieraan kielen oppiminen aikuisena on. Pienelle lapselle tämä tehtävä ei vaikuta olevan ollenkaan hankala, koska jokainen normaalisti kehittyvä lapsi oppii kielen ensimmäisten elinvuosiensa aikana. Syntaksin kehityksessä oleellinen tehtävä on omaksua kohdekielen kielioppi. Tämän lisäksi lapsen tulee oppia kohdekielen sanasto.

Tyypillisesti lapset tuottavat ensimmäiset tunnistettavat sanansa yhden vuoden ikään mennessä. Ensimmäiset ilmaukset ovat yksisanaisia, ja ne osoittavat, että lapset ymmärtävät, miten asiat ovat yhteydessä toisiinsa, vaikka he eivät voi ilmaista näitä yhteyksiä lauseen muodossa, kuten käy ilmi esimerkeistä 1-2.

(1) Milla 1;8: Tulee.

(2) Laura 1;10: Pupu.

(3) Milla 1;10: Suklaata.

Yksisanaisessa vaiheessa ei ole nähtävissä merkkejä produktiivisesta taivutuksesta, vaikka lapset saattavat tuottaa sanoja, joissa on taivutuspääte (esim. 3). Nämä sanat tulkitaan useimmiten lapsen kielessä kokonaisiksi sanoiksi, joissa ei ole taivutuspäätettä. Voidaan siis olettaa, että varhaiset yksisanaiset ilmaukset on omaksuttu leksikaalisina sanoina, vaikka niissä olisikin taivutuspääte.

Lapset alkavat tuottaa kaksisanaisia ilmauksia vähän ennen kahden vuoden ikää, kuten esimerkit 4-5 osoittavat. Tässä kielen kehityksen vaiheessa ilmaantuvat ensimmäiset merkit produktiivisesta taivutuksesta ja syntaksin kehityksestä. 
(4) Milla 1;11: Kato tässä.

(5) Laura 1;11: Pieni kissa.

Kieliopin kehityksen alettua kielen omaksuminen on nopeaa. Kolmevuotiaina lapset ovat omaksuneet kohdekielensä peruskieliopin ja taivutuksen. On selvää, että lapsen tuottama puhe eroaa aikuisen puheesta. Lapset jättävät puheestaan pois elementtejä, jotka ovat pakollisia aikuisen kielessä, kuten lauseen subjekteja, apuverbejä tai artikkeleita (Bloom 1990; Clahsen 1990). Lisäksi lasten tuottamat ilmaukset ovat lyhempiä kuin aikuisten eivätkä lapset käytä puheessaan kaikkia samoja lausetyyppejä kuin aikuiset. Esimerkiksi lasten varhaisesta puheesta puuttuvat relatiivilauseet ja alisteiset lauseet (Clahsen 1990). Lapset tuottavat samassa kehityksen vaiheessa sekä aikuisen kieliopin mukaisia että epäkieliopillisia ilmauksia (Clahsen 1990). Vaikka lapsen elinympäristö vaihtelee, kieltä omaksuessaan jokainen lapsi käy läpi samat vaiheet samassa järjestyksessä. Lopulta kaikilla samaa kieltä puhuvilla lapsilla on hallussaan samat kieliopin säännöt (Lust 2006).

Tutkimuksen aineisto kerättiin kahdelta yksikieliseltä suomalaislapselta videoimalla spontaania puhetta leikkitilanteissa. Aineiston kerääminen aloitettiin, kun lapset alkoivat tuottaa kaksisanaisia ilmauksia, koska tällöin ensimmäiset merkit syntaksin kehityksestä ilmaantuvat puheeseen. Aineiston kerääminen lopetettiin, kun lapset täyttivät kolme vuotta, koska tässä vaiheessa he ovat omaksuneet kohdekielen peruskieliopin. Aineistoa videoitiin lasten kodeissa kerran kuussa, ja yksi kuvauskerta kesti noin tunnin. Kuvaustilanteissa lapset leikkivät erilaisilla leluilla, lukivat kirjoja tai pelasivat pelejä. Kuvauskertoja oli 32, ja aineisto sisälsi yhteensä noin 8500 ilmausta.

Lasten tuottamat ilmaukset litteroitiin, ja ne jaoteltiin kieliopillisiin, epäkieliopillisiin ja epäselviin. Analysoitava aineisto koostui kieliopillisista ja epäkieliopillisista ilmauksista, joita oli kaikkiaan noin 7 50o. Epäkieliopillisiin ilmauksiin kuuluivat esimerkiksi kolmannen persoonan ilmaukset, joissa ei ollut subjektia. Lisäksi aineistoon koodattiin ensimmäisen ja toisen persoonan nollasubjektit. Aineisto analysoitiin lasten käyttämien verbimuotojen osalta monipuolisesti. Tarkastelussa kiinnitettiin huomiota kongruenssin, imperatiivin, konditionaalin, modaaliverbien infinitiivien ja aikamuodon ilmenemiseen ja käyttöön. Tutkimus kohdistui myös lasten kysymyksiin. Aineistossa oli kahdenlaisia kysymyksiä: niitä, jotka sisälsivät kysymyssanan, sekä kyllä/ei-kysymyksiä. Kysymyssanalliset jaettiin kysymyksiin, joissa esiintyi olla-verbi, ja kysymyksiin, joissa oli jokin muu verbi. Jaottelu tehtiin, koska olla-verbillisten kysymysten oletettiin olevan luonteeltaan yksinkertaisia ja kaavamaisia. Myös jokainen kysymyssana eriteltiin erikseen. Lauseiden yhdistämisen näkökulmasta aineistosta analysoitiin alisteiset lauseet sekä relatiivilauseet. Lopuksi aineistosta etsittiin ilmauksia, joissa oli diskurssipartikkeli.

Käsillä olevan tutkimuksen kannalta voidaan nimetä kolme keskeistä lapsen kielen tutkimuksen näkökulmaa. Ensinnäkin aiemmissa lapsen kielen kehityksen tutkimuksissa on tutkittu muun muassa tapaa, jolla lapsen kielestä jäärät pois subjektit (Hyams 1986; Bloom 1990). Näitä aikuisen kielen näkökulmasta puuttuvia subjekteja kutsutaan nollasubjekteiksi. Nollasubjektikielissä (esim. espanja ja suomi) subjektit voidaan jättää pois, kun taas toisissa kielissä subjektit ovat pakollisia (esim. englanti ja ruotsi). Lapset jättävät subjekteja pois, vaikka ne pitäisi fonologisesti ilmaista aikuisen kohdekielessä. Toisen 
näkökulman viitekehykseen tarjoaa aiempi tutkimus niin sanotuista juuri-infinitiiveistä (Rizzi 1993). Juuri-infinitiiviksi kutsutaan ei-finiittistä verbimuotoa, jota lapset käyttävät finiittisessä kontekstissa. Ne esiintyvät usein ilman subjektia. Juuri-infinitiivit ovat lapsen kielen varhaisia verbimuotoja, ja niitä tuotetaan ennen kuin lapsi on omaksunut kongruenssimorfologian. Kolmannen viitekehyksen ulottuvuuden muodostaa aiempi tutkimus funktionaalisten projektioiden kehityksestä lapsen kielen omaksumisessa, koska lapset eivät käytä kaikkia samoja rakenteita kuin aikuiset (Clahsen 1990; Radford 1990; Poeppel \& Wexler 1993). Funktionaaliset projektiot koodaavat lausetyyppiä, aikamuotoa, kongruenssia ja muuta taivutusmorfologiaa. Funktionaaliset projektiot ovat olleet yksi mahdollisuus selittää sitä, miksi lapsen kieli eroaa aikuisen kielestä.

Tutkimukseni ensimmäinen tutkimuskysymys on, kuinka suomenkieliset lapset omaksuvat kohdekielensä subjektit. Suomen kielessä kolmannen persoonan subjektit ovat pakollisia, ja kieliopillisen subjektin pois jättäminen on yleensä epäkieliopillista. Ensimmäisen ja toisen persoonan osalta suomen kielessä on kaksi erillistä kielioppia. Kirjakielessä subjektit jätetään merkitsemättä, kun taas puhutussa kielessä ne useimmiten ilmaistaan fonologisesti. Ensimmäisen ja toisen persoonan subjektien omaksumisen ennustaminen suomen kielessä on epäselvempää kuin kolmannessa persoonassa, koska lapset kuulevat sekä kirja- että puhekieltä. (Ks. myös Bloom 199o.)

Toinen tutkimuskysymys on, mikä verbimuoto on lasten suomen kielen juuriinfinitiivimuoto. Tämä verbimuoto voisi olla jokin infinitiivimuoto kuten monissa muissa kielissä (Clahsen 1990). Toinen vaihtoehto voisi olla imperatiivi, jota on ehdotettu juuri-infinitiivimuodoksi italiassa (Salustri \& Hyams 2003). Kolmas mahdollisuus olisi yksikön kolmannen persoonan muoto, kuten on esitetty espanjassa (Grinstead 1998) ja katalaanissa (Davidson \& Legendre 2003).

Viimeinen tutkimuskysymys on, kuinka funktionaaliset projektiot kehittyvät suomenkielisillä lapsilla. Lapsilla voi olla käytössään kaikki samat funktionaaliset projektiot kuin aikuisilla kielen omaksumisen alusta asti (Poeppel \& Wexler 1993), tai heillä voi olla käytössään osa funktionaalisista projektioista (Clahsen 1990), tai sitten niitä ei ole ollenkaan (Radford 1990). Jos lapsilla ei ole kaikkia funktionaalisia projektioita kielen omaksumisen alusta asti, voidaan kysyä, missä järjestyksessä ne kehittyvät.

Aineiston perusteella lasten suomen kielen kolmannen persoonan subjektien omaksuminen voidaan jakaa kolmeen vaiheeseen. Ensimmäisessä vaiheessa noin puolessa ilmauksista on subjekti. Toisessa vaiheessa noin kaksi kolmasosaa ilmauksista esiintyy subjektin kanssa. Kolmannessa vaiheessa nollasubjektien määrä vähenee lähes aikuisten tasolle, jolloin korkeintaan noin kymmenen prosenttia lasten kolmannen persoonan ilmauksista esiintyy ilman subjektia. Kolmannen persoonan subjektien omaksumisen vaiheet ovat siis suomen kielessä samat kuin tyypillisessä nollasubjektikielessä (Hyams \& Wexler 1993).

Subjektien omaksumisen vaiheet ensimmäisessä ja toisessa persoonassa olivat epäselvempiä kuin kolmannessa persoonassa, koska lasten täytyi omaksua kaksi erillistä kielioppia. Suurin osa ensimmäisen ja toisen persoonan ilmauksista esiintyi ilman subjektia lapsen varhaisessa kielessä. Kun nollasubjektien määrä oli laskenut lähelle aikuisen kielen tasoa ensimmäisessä ja toisessa persoonassa, nollasubjektien määrä lisääntyi uudelleen. Tämä voi viitata kirjakielen piirteiden omaksumiseen, jolloin subjektit 
voidaan joissakin konteksteissa jättää pois. Lapset kuulevat kirjakieltä heille luetuista kirjoista ja lapsille suunnatuista televisio-ohjelmista. Aineistosta havaittiin myös, että ensimmäisen ja toisen persoonan subjektien kehitys oli hiukan jäljessä kolmannesta persoonasta.

Monikon ensimmäisen persoonan subjektit omaksutaan eri tavalla kuin yksikön ensimmäisen persoonan, koska passiiviverbimuotoa käytetään monikon ensimmäisen persoonan konteksteissa puhekielessä. Tutkittujen lasten kieleen monikon ensimmäisen persoonan näkyvät subjektit ilmaantuivat myöhemmin kuin yksikön. Lisäksi nollasubjektien määrä säilyi suurempana kuin muissa persoonissa aineiston keräämisen loppuun asti. Voidaan olettaa, että lapset kuulevat enemmän passiiviverbimuotoja, joihin ei liity subjektia, kuin kolmannen persoonan verbimuotoja, koska aikuisten kielessä samaa muotoa käytetään passiivikonteksteissa ilman subjektia.

Suomen kielessä on kolme mahdollista verbimuotoa juuri-infinitiiviksi: jokin infinitiivimuodoista, imperatiivi tai yksikön kolmannen persoonan muoto. Aineistossani lapset tuottivat kahta infiniittistä verbimuotoa puheessaan. Infinitiivit ylipäänsä olivat hyvin harvinaisia lasten varhaisessa kielessä, lapset yhdistivät nämä infinitiivimuodot muihin verbimuotoihin oikealla tavalla, ja ne harvoin esiintyivät yksin. Näiden havaintojen perusteella voidaan olettaa, että infinitiivi ei voi olla juuri-infinitiivimuoto lasten suomen kielessä.

Lapset tuottivat imperatiiveja aineiston keräämisen alusta asti, mutta näitä verbimuotoja ei käytetty finiittisessä kontekstissa, mitä voitaisiin olettaa juuri-infinitiivimuodolta. Lisäksi imperatiiveja tuotettiin vähemmän kuin yksikön kolmannen persoonan muotoja, ja varhaisessa puheessaan lapset käyttivät vain muutamia verbejä imperatiiveina. Imperatiivien käyttö oli suhteellisen tasaista koko kielen omaksumisen ajan, kun taas juuri-infinitiivimuotojen odotetaan vähenevän kielen omaksumisen edetessä (Lasser 2002). Tästä voidaan todeta, että imperatiivi ei ole juuri-infinitiivimuoto suomen kielessä.

Yksikön kolmannen persoonan muoto on ainoa mahdollinen verbimuoto, joka voisi olla juuri-infinitiivi lapsen suomen kielessä. Yksikön kolmannen persoonan muoto on varhainen lasten tuottama verbimuoto, ja sitä käytetään myös muissa merkityksissä kuin yksikön kolmannessa, pääasiassa yksikön ensimmäisessä kuten esimerkeissä 6-7. Toisin kuin aikuisen kielessä lapset käyttivät yksikön kolmannen persoonan muotoja subjektin kanssa, kuten esimerkki 6 osoittaa, tai ilman subjektia kuten esimerkeissä 7-8.

(6) Milla 2;0: Milla ottaa.

(7) Milla 1;10: Laittaa takasin. ('minä laitan takaisin')

(8) Laura 2;0: Pysyy. ('minä pysyn')

Yksikön kolmannen persoonan muoto oli hyvin yleinen lapsen kielessä, ja sen käyttö väheni ajan kuluessa, kuten tapahtuu juuri-infinitiivimuodoille myös muissa kielissä. Nämä tiedot tukevat havaintoa, että yksikön kolmannen persoonan muoto on juuriinfinitiivimuoto lapsen suomen kielessä. Aikuisen kielessä tämä verbimuoto on finiittinen, mutta lapsen kielessä voidaan olettaa, että se ei juuri-infinitiivivaiheessa kongruoi samassa mielessä kuin aikuisen kielessä. Yksikön kolmannen persoonan muoto muut- 
tuu finiittiseksi verbimuodoksi lapsen kielessä, kun lapset ovat omaksuneet yksikön ensimmäisen persoonan verbimuodon.

Lapset tuottivat menneen ajan verbimuotoja aineiston kuvaamisen alusta asti, joten heillä oli ainakin yksi funktionaalinen projektio aikamuodolle kielen omaksumisen tässä vaiheessa, kuten esimerkit 9-10 osoittavat.

(9) Milla 1;8: Kaatu.

(10) Laura 1;10: Heräs.

Koska lapset eivät käyttäneet modaaliverbejä tai muita moduksia kuin indikatiivia varhaisessa kielessään, on mahdollista, että aikamuodolla ei lapsen kielessä ole kaikkia samoja ominaisuuksia kuin aikuisen kielessä ja lapsi olisi vasta omaksumassa aikamuototasoa.

Koska lapset alkoivat tuottaa kongruenssimorfologiaa produktiivisesti yksikön ensimmäisessä persoonassa 2;2-2;3 ikävuoden välillä (esim. 11-12), lapsilla ei ollut funktionaalista projektiota kongruenssille kielen omaksumisen alusta asti.

(11) Laura 2;2: Minä teen tornin.

(12) Milla 2;3: Haluun tämän.

Voidaan siis olettaa, että lasten suomen kielessä ei ole kaikkia samoja funktionaalisia projektioita kuin aikuisella.

Lapset tuottivat yksikön kolmannen persoonan negaatiota hyvin varhain (ks. esim. 13-14).

(13) Milla 1;8: Ei tiiä.

(14) Laura 1;11: Ei pääse. [L yrittää avata lelua]

Negaatio saattoi olla läsnä kielen omaksumisen alusta asti, tai sitten se ilmaantui vähän aineiston keräämisen alkamisen jälkeen. Näin ollen lapsilla oli yksi funktionaalinen projektio negaatiolle hyvin varhain. Lapset tuottivat negaatiota menneessä ajassa hyvin harvoin, joten on vaikeaa sanoa, oliko heillä kaksi funktionaalista projektiota vai vain yksi, jossa kielen omaksumisen alusta asti sijaitsevat sekä negaatio että aikamuoto. Jos lapsilla olisi vain yksi funktionaalinen projektio, aikamuoto ja negaatio voisivat kilpailla samasta funktionaalisesta projektiosta kielen omaksumisen varhaisessa vaiheessa.

Näkyvien yksikön ensimmäisen persoonan subjektien määrä alkoi lisääntyä samassa vaiheessa, kun lapset olivat omaksuneet yksikön ensimmäisen persoonan kongruenssin. Samassa vaiheessa kolmannen persoonan nollasubjektit alkoivat vähetä. Yksikön ensimmäisen persoonan näkyvien subjektien lisääntyminen voi tarkoittaa sitä, että kongruenssi on ilmaantumassa lasten kieleen. Koska kolmannen persoonan näkyvät subjektit lisääntyivät samassa vaiheessa, voidaan olettaa, että kolmannen persoonan verbimuoto on muuttumassa kongruoivaksi muodoksi eikä olisi enää vain juuri-infinitiivimuoto. Nämä tulokset tukevat sitä oletusta, että kongruenssin ja subjektien omaksuminen ovat yhteydessä toisiinsa (Radford 1990). Juuri-infinitiiveillä 
ja kongruenssilla on myös yhteys, eli jos juuri-infinitiivimuoto on uudelleen analysoitu yksikön kolmannen persoonan kongruoivaksi muodoksi, kongruenssin ja nollasubjektien välinen yhteys pätee myös yksikön kolmannen persoonan kohdalla.

Lapset tuottivat kysymyssanalla muodostettuja kysymyksiä melkein aineiston keräämisen alusta asti (ks. esim. 15-16).

(15) Laura 2;0: Mitä toi on?

(16) Milla 2;2: Missä on minun?

Suurimmassa osassa varhaisia kysymyksiä oli verbi olla. Voidaan olettaa, että nämä kysymykset ovat syntaktiselta rakenteeltaan yksinkertaisempia kuin monimutkaiset kysymykset, ja tässä kielen kehityksen vaiheessa lapsi kykenee muodostamaan joitain yksinkertaisia kysymyksiä.

Lapset alkoivat tuottaa monimutkaisempia kysymyksiä 2;2-2;3 ikävuoden kohdalla (ks. esim. 17). Muulla kuin konjunktiolla että muodostetut alisteiset lauseet (ks. esim. 18-19) ja ilmaukset, joissa oli diskurssipartikkeli, ilmestyivät lasten puheeseen noin 2;3 vuoden iässä. Samaan aikaan ilmestyivät kyllä/ei-kysymykset. Kaikki nämä rakenteet ilmaantuivat yhtä aikaa monimutkaisempien kysymysten kanssa.

(17) Milla 2;5: Mitä siellä tapahtuu?

(18) Laura 2;2: Ku tippu mullakin kasvi.

(19) Milla 2;11: Tämä on kivaa kun on nokkela.

Konjunktiolla että muodostettuja alistettuja lauseita tuli lasten kieleen kahden ja puolen vuoden iässä (ks. esim. 20-21).

(20) Milla 2;6: Vielä tarvitaan nää tänne että ne pysyy.

(21) Laura 2;6: Että minua pelottaa olla ylhäällä.

Relatiivilauseet olivat harvinaisia aineistossani, mikä voi tarkoittaa sitä, että suomenkielinen lapsi alkaa käyttää niitä myöhään. Varhaiset kysymykset voivat toimia laukaisijana muille funktionaalisille projektioille tai tarkoittaa sitä, että funktionaaliset projektiot ovat ilmaantumassa lapsen puheeseen.

Lapset käyttivät suurinta osaa rakenteista aikuisten kielen kieliopin mukaan alusta asti. Ainoa iso ero aikuisen kieleen oli, että lapset käyttivät alisteisia lauseita ilman päälausetta, kuten esimerkit 18 ja 21 osoittavat.

Aineistosta tehdyt havainnot funktionaalisten projektioiden kehityksestä eivät tue näkemystä, että lapsilla olisi käytössään kaikki samat funktionaaliset projektiot kuin aikuisilla, koska kongruenssi, monimutkaiset kysymykset, alisteiset lauseet ja relatiivilauseet sekä diskurssipartikkelit puuttuvat lasten varhaisesta kielestä. Toisaalta aineisto tukee sitä näkemystä, että funktionaaliset projektiot kehittyvät vähitellen lapsen puheeseen, koska konjunktio että omaksutaan myöhemmin kuin muut rakenteet. Lauseissa, joissa konjunktio että esiintyy, on yksi funktionaalinen projektio enemmän kuin muissa alisteisissa lauseissa tai kysymyksissä. 
Tutkimukseni osoittaa, että kolmannen persoonan subjektit kehittyvät suomenkielisillä lapsilla samalla tavalla kuin kielissä, joissa subjektit ovat pakollisia kaikissa persoonissa. Aluksi lapset siis jättävät subjekteja pois, vaikka ne ovat pakollisia aikuisen kielessä. Ensimmäisen ja toisen persoonan subjektimalli on monimutkaisempi, koska lapset kuulevat kahta erilaista kielioppia. Malli on samanlainen kuin kolmannessa persoonassa, mutta ensimmäisessä ja toisessa persoonassa nollasubjektit lisääntyvät uudelleen lähellä kolmen vuoden ikää, mikä saattaa viitata kirjakielen omaksumiseen ja kielimuotoon, jota lapset kuulevat heille luetuista kirjoista ja lapsille suunnatuista televisio-ohjelmista.

Tutkimuksestani käy ilmi, että suomen kielen juuri-infinitiivimuoto on yksikön kolmannen persoonan muoto. Tämä verbimuoto poikkeaa muista kielistä, koska suurimmassa osassa tutkituista kielistä juuri-infinitiivi on ei-finiittinen verbimuoto (Clahsen 1990; Rizzi 1993). Aikuisten kielessä yksikön kolmannen persoonan muoto on finiittinen verbimuoto. Lapsen kielessä verbimuodon voidaan olettaa olevan ei-finiittinen niin kauan, kunnes kongruenssi ilmaantuu lapsen puheeseen.

Tutkimukseni mukaan suomenkielisillä lapsilla on ainakin yksi funktionaalinen projektio aikamuodolle kaksisanaisesta vaiheesta lähtien. Funktionaalisten projektioiden kehitys seuraa niin sanottua orgaanista kielioppia (Vainikka \& Young-Scholten 2011), jonka mukaan funktionaaliset projektiot omaksutaan vähitellen yksi kerrallaan. Ainoana erona on, että orgaanisessa kieliopissa oletetaan, että lapsilla ei ole yhtään funktionaalista projektiota kielen kehityksen alussa. Kuitenkin suomenkieliset lapset ilmaisevat funktionaalisen projektion aikamuodolle jo kaksisanaisen vaiheen alusta asti.

\section{Lähteet}

Bloom, Paul 1990: Subjectless sentences in child language. - Linguistic Inquiry 21 s. 491-504.

Clahsen, Harald 1990: Constraints on parameter setting. A grammatical analysis of some acquisition in stages in German child language. - Language Acquisition 1 s. 361-391. http:// doi.org/10.1207/s15327817lao104_3.

Davidson, Lisa - Legendre, Géraldine 2003: Defaults and competition in the acquisition of functional categories in Catalan and French. - Rafael Nuñez-Cedeño, Luis López \& Richard Cameron (toim.), A romance perspective on language knowledge and use s. 273-290. Amsterdam: John Benjamins.

Grinstead, John Allen Ray 1998: Subjects, sentential negation and imperatives in child Spanish and Catalan. Los Angeles: University of California.

Hyams, Nina 1986: Language acquisition and the theory of parameters. Dordrecht: Reidel.

Hyams, Nina - Wexler, Kenneth 1993: On the grammatical basis of null subjects in child language. - Linguistic Inquiry 24 S. 421-459.

LASSER, INGEBORG 2002: The roots of root infinitives. Remarks on infinitival main clauses in adult and child language. - Linguistics 40 s. 767-796. http://doi.org/10.1515/ling.2002.030.

Lust, BARBAR 2006: Child language. Acquisition and growth. New York: Cambridge University Press.

Poeppel, David - Wexler, Kenneth 1993: The full competence hypothesis of clause 
structure in early German. - Language 20 s. 1-33. http://doi.org/10.2307/416414.

RADFORD, ANDREW 1990: Syntactic theory and the acquisition of English syntax. The nature of early child grammars of English. London: Blackwell.

Rizzi, Luigi 1993: Some notes on linguistic theory and language development. The case of root infinitives. - Language Acquisition 3 s. 371-393. http://doi.org/10.1207/

s15327817lao304_2.

Salustri, Manola - Hyams, Nina 2003: Is there an analogue to the RI stage in the null subject languages? - Barbara Beachley, Amanda Brown \& Frances Conlin (toim.), Proceedings of the Annual Boston University Conference on Language Development s. 692-703. Somerville, MA: Cascadilla.

Vainikka, Anne - Young-Scholten, Martha 2011: The acquisition of German. Introducing organic grammar. Berlin: Walter de Gruyter.

Taija Saikkonen: The development of Finnish syntax between the ages of 1 year, 8 months and 3 years. University of Helsinki. Department of Digital Humanities. Studies in Cognitive Science 8. Helsinki: Helsingin yliopisto 2018. Väitöskirja on luettavissa osoitteessa http:// urn.fi/URN:ISBN:978-951-51-4216-0.

Kirjoittajan yhteystiedot:

etunimi.sukunimi@elisanet.fi 